\title{
Influence of class size on students' classroom discipline, engagement and communication: a case study of senior secondary schools in Ekiti state, Nigeria
}

\author{
Oluwatosin Victor Ajayi ${ }^{{ }^{*}}$, Christina Tanko Audu ${ }^{2}$ and Evelyn Ehi Ajayi ${ }^{1}$ \\ ${ }_{1}^{1}$ Department of Curriculum and Teaching, Benue State University, Makurdi, Benue State, Nigeria. \\ ${ }^{2}$ Department of Integrated Science, College of Education, Zing, Taraba State, Nigeria.
}

Accepted 26 October, 2017

In this study, the influence of class size on students' classroom discipline, engagement and communication was examined. A sample of 128 senior secondary school teachers from 16 purposely selected secondary schools out of a population of $\mathbf{4 5 2 9}$ senior secondary teachers from Ekiti State, Nigeria was used for the study. The study adopted a descriptive survey research design. The instrument used for data collection was Influence of Class Size on Classroom Discipline, Engagement and Communication Questionnaire (ICSCDECQ) with the reliability value of 0.78 using Cronbach Alpha (KR-21). Four research questions and three null hypotheses guided the study. The research questions were answered using Mean rating and Standard Deviation scores while the null hypotheses were tested using Chi-square. The study revealed that class size has significant influence on senior secondary classroom discipline, engagement and communication. It was recommended among others that, senior secondary schools in Ekiti State, Nigeria should adopt a maximum of 40:1 studentteacher ratio (small class size) for effective classroom discipline, engagement and communication.

Key words: Class size, classroom discipline, classroom engagement, classroom communication.

\section{INTRODUCTION}

Education is the systematic training of individual in order to bring about positive change in his or her behaviour so as to become fulfilled citizen (Angelo, 2008). Across the globe, trends in education have reflected significant increase in students' enrolment (Ademola, 2014). This is very evident in Nigeria with an upward trend in school enrolment at all levels of education after the civil war in 1970. Nigeria, like most of the countries across the globe has adopted and implemented to a large extent the Education For All (EFA) policy of the United Nations (UN), which has in no small measure resulted in the increased students population at all levels of education. The increased numbers in enrolment have led to another educational problem which piqued the interest of educators, particularly when this increased number is juxtaposed with students' classroom management and engagement. The increased figure in enrolment has led to increased number of students in a classroom. According to Yusuf (2015), classrooms are used as appropriate places for seeking and acquiring education usually from a teacher to the learners.

In this present study, classroom size is the population of a given class in terms of number of students per teacher. For instance, Canada, Australia, Romania, Czech Republic, USA and Slovenia has less than 30 students recommended for a standard class size; Turkey, Netherlands and Norway have 20 or less students for a standard class size; Japan and Singapore have above 30 students as a standard class size (Mokobia and Okoye, 2011). These fall within the UNESCO recommended standard (25) for number of students in a classroom. The National Policy on Education (2013) recommended an 
average of 40 students per class as the standard class size in Nigeria. Two class sizes are normally distinguishable in the educational sector. A large class size falls within 41 and above learners to one teacher while small class size is within 15-40 learners to one teacher (Aliu, 2005). Many scholars including Yusuf (2015), Molnar (1998), Booze and Maloney (2001) and Shuaibu (2003) cited in Yusuf (2015) all support this classification of class sizes. Therefore, in this present study, class size with 1 - 40 students per teacher will be categorized as small class size while class size with 41 and above students per teacher will be categorized as large class size.

Mokobia and Okoye (2011) highlighted that educators universally identify class size as a desirable attribute of the educational system. Thus, this has raised widely reported debate among educational stakeholders such as academics, parents and policy makers over the educational consequences of class size. Class size is refers to as students to teacher ratio per class (Ali, 2012). Class size According to Adeyemi (2008) referred to as an educational tool that can be used to describe the average number of students per class in a school. In the view of Ikolo (2011), class size equally means group which is a set of persons among whom there exist a definable or observable set of relations. The word group then can refer not only to a set of persons but to a place where the interaction occurs. Dror (2009) noted that class size has become a phenomenon often mentioned in the educational literature as an influence on students' socializing pattern and academic performance, quality of instruction, administration and school budgets. The scholar added that class size is an administrative decision which teachers have little or no control. Kedney (2013) described class size as a tool that can be used to measure performance of the education system. Imoke (2006) remarked that optimum class size in a school system implies rational coordination of educational infrastructures, subject to available number of students in order to attain high level of productivity.

Ogunyemi and Hassan (2011) maintained that the issue of small or large class size can be counterproductive. In remote and even local areas, classes are found to be over-congested which is indeed an indication of the dearth of educational facilities in schools. The issue of large class sizes and the associated consequences is paramount. The phenomenon of large classes is fast becoming the vogue of senior secondary schools in Nigeria and in most developing countries. The large class syndrome has been attributed to the expansion in annual students' enrolment. Sesugh (2012) discovered that there is tremendous increase in the enrolment of students and in the average size of classrooms in Nigeria senior secondary schools these days from 30 - 40 students to $60-75$ or even more. Though, open enrolment in schools is laudable, yet, the deficiency is in the corresponding provision of adequate infrastructures, inadequate classrooms, short supply of teachers, dilapidated structures and classrooms which look like poultry in some schools. Seats and desks which are basic classroom requirements are insufficient and in some senior secondary schools, students are sitting on ransacked furniture and some even sit on bare floor.

The size of classes has become increasingly unmanageable, leaving the teachers with the impossible task of giving individual attention to the learner's needs. The teachers' eye contact with the learner in class becomes so dissipated that a number of poorly motivated learners can form small committees at the back of the class to engage in non-school discussion, while the teacher is busy teaching. Continuous assessments are dreaded by teachers when they consider the staggering number of scripts to be marked and recorded. In modern education, attention is centered on the needs and comfort of the learner, how the learning is distributed by social background and may be influenced by the structural and organizational properties of the school. Thus, attention is centered on class size which allows pupils to learn effectively without disturbing one another. Often times, class size which implies number of students is seen as the challenge teachers have to face in maintaining effective classroom management and engagement.

In a learning community based on social constructivist theory, the teacher acts as a collaborator in the production of knowledge within the classroom. The premise is that when teachers help students construct knowledge through classroom engagement. The number of students in a class has the potential to influence not just the students' interaction pattern in different ways but also the management of such a class. Effective classroom management implies more than eliciting student cooperation in maintaining order. It also implies that worthwhile learning activities engaging to students are taking place continuously in the classroom. In a wellmanaged classroom, the teacher prepares a physical environment suitable for learning, develops rules of conduct, maintains student attention and participation in lessons, and monitors students' assignments and progress toward the desired learning outcome (Doyle, 2014). Classroom discipline refers to the wide variety of skills and techniques that teachers use to keep students organized, orderly, focused, attentive on task, and academically productive during a class. When classroom discipline strategies are executed effectively, teachers minimize the behaviours that impede learning for both individual students, while maximizing the behaviours that facilitate or enhance learning (Ayuba, 2013).

Makinde (2011) opine that to build effective classroom management, teachers should model appropriate behaviour and use appropriate classroom discipline methods. Class sizes have been incriminated as being responsible for the in conducive teaching and learning environment (Tobi, 2013). On one side, classroom congestion in terms of large class is blamed and on the 
other hand, low utilization of classrooms in the sense of small class size have been identified as a common feature of senior secondary school in Nigeria. Conflicts have often appeared on the ideal class size.

Students' classroom engagement has been enlisted amongst key elements of educational success (Creemers, 2012). One way for students to shoulder the responsibility for learning is for them to be the readers, writers, speakers, listeners, thinkers in the classroom through active classroom engagement (Vacca, 2011). Student engagement have been defined as the level of participation and intrinsic interest that a student shows in the classroom (Newmann, 2009). Classroom engagement also involves both behaviours and attitudes towards learning (Johnson, 2014). Some studies have shown that class size have no relationship with pupils' classroom engagement (Rowe, 2012; Roland, 2015) while some studies have shown that class size have positive relationship with pupils' classroom engagement (Mezieobi, 2012; Aliu, 2015).

Communication process is vital to effective learning within a classroom environment. Classroom instruction that produce positive result acknowledges the need for a liberal use of non-verbal cues, student involvement and term communication. Students' involvement during classroom discussions typically fosters a healthy communication process (Nwaubani, 2007). Some studies have shown that class size have no relationship with classroom communication (Nwaubani, 2007; Nosiri, 2012) while some studies have shown that class size have strong relationship with classroom communication (Pascarella, 2012; Kehinde, 2014; Johnson, 2015). It is on this note that the study examined the influence of class size on senior secondary students classroom discipline, engagement and communication in senior secondary schools in Ekiti State, Nigeria as a study area. Specifically, the study:

i.) Determined the influence of class size on senior secondary students' classroom discipline

ii.) Ascertained the influence of class size on senior secondary students' classroom engagement

iii.) Determined the influence of class size on senior secondary students' classroom communication

iv.) Ascertained the perceived major causes of large class size

\section{Research questions}

The following research questions guided this study:

i.) How does class size influence senior secondary students' classroom discipline?

ii.) How does class size influence senior secondary students' classroom engagement? iii.) How does class size influence senior secondary students' classroom communication?

iv.) What are the perceived major causes of large class size?

\section{Hypotheses}

The following null hypotheses were tested:

i.) Class size has no significant influence on senior secondary students' classroom discipline

ii.) Class size has no significant influence on senior secondary students' classroom engagement

iii.) Class size has no significant influence on senior secondary students' classroom communication

\section{Research design and procedure}

The study adopted a descriptive survey research design. The design was considered appropriate because the design sought to obtain information that discloses existing phenomena by asking individual about their perceptions, attitude, behaviour or beliefs. The study area was Ekiti State, Nigeria. A sample of 128 senior secondary school teachers from 16 purposively selected secondary schools from the 16 Local Government Area of Ekiti State, Nigeria was used for the study.

An instrument known as Influence of Class Size on Classroom Discipline, Engagement and Communication Questionnaire (ICSCDECQ) developed by the researchers and validated by four experts in science education/measurement and evaluation was used to collect the data. ICSCDECQ contained two sections. Section "A" contained demographic information of the respondents, while section " $B$ " contained a 20-item questionnaire which was intended to help respondents express their perceptions on the influence of class size on classroom management and engagement. Each of the items is a 5 -point Likert-rating scale with 5 responses options. The options are Strongly Agree (SA), Agree (A), Undecided (U), Disagree (D) and Strongly Disagree (SD). ICSCDECQ yielded a reliability coefficient of 0.78 using Cronbach Alpha (KR-21). Two research questions and two null hypotheses guided the study. After collecting the data using ICSCDECQ, the research questions were answered using Mean and Standard Deviation scores while the null hypotheses were tested using Chi-square.

\section{RESULTS AND TABLES}

\section{Research question one}

How does class size influence senior secondary students' classroom discipline? The answer to research question one is contained in Table 1.

Table 1 revealed that the mean ratings of items $1,2,6$ 
Table 1. Mean and standard deviation scores of respondents on the influence of class size on classroom discipline.

\begin{tabular}{|c|c|c|c|c|c|c|c|c|c|}
\hline $\begin{array}{l}\text { Item } \\
\text { No }\end{array}$ & Item Description & SA & $\bar{A}$ & $\mathbf{U}$ & $\bar{D}$ & SD & $\bar{X}$ & ST.D & Decision \\
\hline 1. & $\begin{array}{l}\text { I start lessons on time and continue without } \\
\text { any interruption (students disruptive } \\
\text { behaviour such as noise) in a small class } \\
\text { size }\end{array}$ & 67 & 42 & 1 & 13 & 5 & 3.45 & 0.93 & Accepted \\
\hline 2. & $\begin{array}{l}\text { I consistently enforce the classroom rule } \\
\text { and procedures, so discipline problems are } \\
\text { infrequent in a small class size }\end{array}$ & 72 & 45 & - & 9 & 2 & 3.74 & 1.12 & Accepted \\
\hline 3. & $\begin{array}{l}\text { I easily ensure that transition from one } \\
\text { learning activity to another is done with no } \\
\text { loss of instructional time in a large class } \\
\text { size }\end{array}$ & 3 & 12 & 2 & 40 & 71 & 2.49 & 0.51 & Rejected \\
\hline 4. & $\begin{array}{l}\text { I usually attend to the needs of individual } \\
\text { students in a large class size }\end{array}$ & 4 & 7 & 4 & 32 & 81 & 2.74 & 0.72 & Rejected \\
\hline 5. & $\begin{array}{l}\text { I have to stop during lessons to address } \\
\text { students misbehaviour in a small class size }\end{array}$ & 5 & 4 & - & 30 & 89 & 2.81 & 0.84 & Rejected \\
\hline 6 & $\begin{array}{l}\text { f feel my classroom management } \\
\text { techniques are inadequate in a large class } \\
\text { size }\end{array}$ & 82 & 35 & - & 9 & 2 & 3.94 & 1.29 & Accepted \\
\hline \multirow[t]{2}{*}{7} & $\begin{array}{l}\text { I am able to attend to two events } \\
\text { simultaneously in a small class size without } \\
\text { being diverted unduly by disruptions }\end{array}$ & 79 & 33 & - & 12 & 4 & 4.08 & 1.41 & Accepted \\
\hline & Cluster mean and Standard Deviation & & & & & & 3.32 & 0.97 & Accepted \\
\hline
\end{tabular}

and 7 are $3.45,3.74,3.94$ and 4.08 respectively with the corresponding standard deviation of $0.98,1.12,1.29$ and 1.41. All the mean ratings of item $1,2,6$ and 7 are above the cut-off point of 3.0. This implies that the respondents agreed that they start lessons on time and continue without any interruption (students disruptive behaviour such as noise) in a small class size; they consistently enforce the classroom rule and procedures, so discipline problems are infrequent in a small class size; they feel that classroom management techniques used are inadequate in a large class size; they are able to attend to two events simultaneously in a small class size without being diverted unduly by disruptions

Table 1 also revealed that the mean ratings of items 3 , 4 and 5 are $2.49,2.74$ and 2.81 respectively with the corresponding standard deviation of $0.51,0.72$ and 0.84 . All the mean ratings of items 3,4 and 5 are below the cutoff point of 3.0. This implies that the respondents disagreed that they easily ensure that transition from one learning activity to another is done with no loss of instructional time in a large class size; they usually attend to the needs of individual students in a large class size; they have to stop during lessons to address students misbehaviour in a small class size. The cluster mean of 3.32 with the standard deviations of 0.97 was also found to be above the cut-off point of 3.0. This implies that class size have influence on students' classroom discipline in senior secondary schools in Ekiti State, Nigeria.

\section{Research question two}

How does class size influence senior secondary students' classroom engagement? The answer to research question two is presented in Table 2.

Table 2 revealed that the mean ratings of items 8,9 , 12,13 and 14 are $3.66,3.75,3.61,3.72$ and 3.85 respectively with the corresponding standard deviation of $1.04,1.11,1.02,1.09$ and 1.19. All the mean ratings of items $8,9,12,13$ and 14 are above the cut-off point of 3.0. This implies that the respondents agreed that they don't usually assign independence practice activities such as seatwork and homework to students in a large class size; they always engage the students in classroom discussion in a small class size; they encourage students to solve their problem between each other independently when doing group work in a small class size; they dislike engaging students to solve their problem between each other independently when doing group work in a large class size because it will lead to disruptive behaviour; they have an increasingly difficult job trying to engage students in practice activities such as seatwork, practical work and homework in a large class size

Table 2 also revealed that the mean ratings of items 10 and 11 are 2.76 and 2.47 respectively with the corresponding standard deviation of 0.73 and 0.49 . All the mean ratings of items 10 and 11 are below the cut-off point of 3.0. This implies that the respondents disagreed that they usually maintains the flow of activities by stimulating students involvement in a large class size; they allow students to frequently ask questions during class session in a large class size. The cluster mean of 3.40 with the standard deviations of 0.95 was also found to be above the cut-off point of 3.0. This implies that class 
Table 2. Mean and standard deviation scores of respondents on the influence of class size on classroom engagement.

\begin{tabular}{|c|c|c|c|c|c|c|c|c|c|}
\hline $\begin{array}{l}\text { Item } \\
\text { No }\end{array}$ & Item Description & SA & $\mathbf{A}$ & $\mathbf{U}$ & D & SD & $\bar{X}$ & ST.D & Decision \\
\hline 8. & $\begin{array}{l}\text { don't usually assign independence } \\
\text { practice activities such as seatwork and } \\
\text { homework to students in a large class size }\end{array}$ & 73 & 38 & 2 & 11 & 4 & 3.66 & 1.04 & Accepted \\
\hline 9. & $\begin{array}{l}\text { I always engage the students in classroom } \\
\text { discussion in a small class size }\end{array}$ & 70 & 39 & 1 & 12 & 6 & 3.75 & 1.11 & Accepted \\
\hline 10. & $\begin{array}{l}\text { I usually maintains the flow of activities by } \\
\text { stimulating students involvement in a large } \\
\text { class size }\end{array}$ & 5 & 13 & - & 31 & 79 & 2.76 & 0.73 & Rejected \\
\hline 11. & $\begin{array}{l}\text { I allow students to frequently ask questions } \\
\text { during class session in a large class size }\end{array}$ & 12 & 14 & - & 43 & 59 & 2.47 & 0.49 & Rejected \\
\hline 12. & $\begin{array}{l}\text { I encourage students to solve their problem } \\
\text { between each other independently when } \\
\text { doing group work in a small class size }\end{array}$ & 58 & 53 & 2 & 13 & 2 & 3.61 & 1.02 & Accepted \\
\hline 13 & $\begin{array}{l}\text { I dislike engaging students to solve their } \\
\text { problem between each other } \\
\text { independently when doing group work in a } \\
\text { large class size because it will lead to } \\
\text { disruptive behaviour }\end{array}$ & 61 & 47 & - & 17 & 3 & 3.72 & 1.09 & Accepted \\
\hline \multirow[t]{2}{*}{14} & $\begin{array}{l}\text { I have an increasingly difficult job trying to } \\
\text { engage students in practice activities such } \\
\text { as seatwork, practical work and homework } \\
\text { in a large class size }\end{array}$ & 52 & 60 & - & 11 & 5 & 3.85 & 1.19 & Accepted \\
\hline & Cluster Mean and Standard Deviation & & & & & & 3.40 & 0.95 & Accepted \\
\hline
\end{tabular}

size influence students' classroom engagement in senior secondary schools in Ekiti State, Nigeria.

\section{Research question three}

How does class size influence senior secondary students' classroom communication? The answer to research question three is presented in Table 3.

The result presented in Table 3 showed that the mean ratings of items $15,16,18,19$ and 20 are $3.71,3.54$, $3.81,3.89$ and 3.66 respectively with the corresponding standard deviation of $1.08,0.99,1.17,1.24$ and 1.04. All the mean ratings of items 15, 16, 18, 19 and 20 are above the cut-off point of 3.0. This implies that the respondents agreed that they always write on black board to explain a concept because students cannot hear my voice very well during classroom session in a large class size; they always holds students attention during lessons in a small class size; they speaks or communicate clearly during classroom session in a small class size; they have an increasingly difficult job trying to communicate effectively in a large class size; they feel that most students jot down note during classroom session because they can hear my voice clearly in a small class size.

Table 3 also revealed that the mean rating of item 17 is 2.45 with the corresponding standard deviation of 0.48 . The mean rating of item 17 is below the cut-off point of 3.0. This implies that the respondents disagreed that they always has a firm grasp of the class when teaching in a large class size. The cluster mean of 3.51 with the standard deviations of 1.00 was also found to be above the cut-off point of 3.0. This implies that class size influence students' classroom communication in senior secondary schools in Ekiti State, Nigeria.

\section{Research question four}

What are the perceived causes of large class size?

The result in Table 4 revealed that insufficient/dilapidated classroom, insufficient teaching staff, inadequate infrastructural facilities, budgetary constraints ranked the major causes of large class size in senior secondary school in Ekiti State, Nigeria.

\section{Hypothesis one}

Class size has no significant influence on senior secondary students' classroom discipline. The answer to hypothesis one is presented in Table 5.

The results in Table 5 reveal that $75 \%$ of the respondents agreed that class size has significant influence on senior secondary students' classroom discipline as against $32 \%$ of respondents who disagreed. The chi-square calculated value of 87.69 was greater than the chi-square table value of 3.84 checked at 0.05 level of significance and at 1 degree of freedom. The null hypothesis is therefore rejected. This implies that class size has significant influence on senior secondary students' classroom discipline. 
Table 3. Mean and standard deviation scores of of respondents on the influence of class size on classroom communication.

\begin{tabular}{|c|c|c|c|c|c|c|c|c|c|}
\hline $\begin{array}{l}\text { Item } \\
\text { No }\end{array}$ & Item Description & SA & $\mathbf{A}$ & $\mathbf{U}$ & D & SD & $\mathbf{X}$ & ST.D & Decision \\
\hline 15. & $\begin{array}{l}\text { I always write on black board to } \\
\text { explain a concept because } \\
\text { students cannot hear my voice } \\
\text { very well during classroom } \\
\text { session in a large class size }\end{array}$ & 62 & 49 & - & 15 & 2 & 3.71 & 1.08 & Accepted \\
\hline 16. & $\begin{array}{l}\text { I always holds students attention } \\
\text { during lessons in a small class } \\
\text { size }\end{array}$ & 56 & 53 & 1 & 17 & 1 & 3.54 & 0.99 & Accepted \\
\hline 17. & $\begin{array}{l}\text { I always has a firm grasp of the } \\
\text { class when teaching in a large } \\
\text { class size }\end{array}$ & 10 & 16 & - & 40 & 62 & 2.45 & 0.48 & Rejected \\
\hline 18. & $\begin{array}{l}\text { I speaks or communicate clearly } \\
\text { during classroom session in a } \\
\text { small class size }\end{array}$ & 68 & 38 & 2 & 14 & 6 & 3.81 & 1.17 & Accepted \\
\hline 19. & $\begin{array}{l}\text { I have an increasingly difficult job } \\
\text { trying to communicate effectively } \\
\text { in a large class size }\end{array}$ & 77 & 26 & 1 & 19 & 5 & 3.89 & 1.24 & Accepted \\
\hline \multirow[t]{2}{*}{20} & $\begin{array}{l}\text { I feel that most students jot down } \\
\text { note during classroom session } \\
\text { because they can hear my voice } \\
\text { clearly in a small class size }\end{array}$ & 75 & 36 & - & 15 & 2 & 3.66 & 1.04 & Accepted \\
\hline & \multicolumn{2}{|l|}{ Cluster Mean and Standard Deviation } & & & & & 3.51 & 1.00 & epted \\
\hline
\end{tabular}

Table 4. Mean Scores of Respondents' Causes of Large Class Size in order of Ranking $(n=128)$.

\begin{tabular}{lcc}
\hline Perceived causes of large class size & Mean scores & Ranking \\
\hline Insufficient/dilapidated classrooms & 2.55 & $1^{\text {st }}$ \\
Insufficient teaching staff & 2.60 & $2^{\text {nd }}$ \\
Inadequate infrastructural facilities & 2.76 & $3^{\text {rd }}$ \\
Budgetary constraints & 3.85 & $4^{\text {th }}$ \\
Lack of physical space & 4.10 & $5^{\text {th }}$ \\
Unexpected high enrollment & 4.94 & $6^{\text {th }}$ \\
Change in certificate requirement & 5.18 & $7^{\text {th }}$ \\
\hline
\end{tabular}

Table 5. Chi-square test of the influence of class size on classroom discipline.

\begin{tabular}{|c|c|c|c|c|c|c|c|}
\hline Opinions & $\begin{array}{l}\text { Observed } \\
\text { Frequency }\end{array}$ & $\begin{array}{l}\text { Expected } \\
\text { Frequency }\end{array}$ & Df & Level of Sig. & $\mathrm{X}^{2 \text {-cal }}$ & $X^{2 \text {-tab }}$ & Decision \\
\hline $\begin{array}{l}\text { Not } \\
\text { Significant }\end{array}$ & $32(25 \%)$ & $64.0(50 \%)$ & 1 & 0.05 & 87.69 & 3.84 & \\
\hline Significant & $96(75 \%)$ & $64.0(50 \%)$ & & & & & Significan \\
\hline
\end{tabular}

\section{Hypothesis two}

Class size has no significant influence on senior secondary students' classroom engagement. The answer to hypothesis two is presented in Table 6.

Table 6 reveals that $62 \%$ of the respondents agreed that class size has significant influence on senior secondary students' classroom engagement as against $38 \%$ of respondents who disagreed. The chi-square calculated value of 98.79 was greater than the chi-square table value of 3.84 checked at 0.05 level of significance and at 1 degree of freedom. The null hypothesis is therefore rejected. This implies that class size has significant influence on senior secondary students' classroom engagement. 
Table 6. Chi-square test of the influence of class size on classroom engagement.

\begin{tabular}{lccccccc}
\hline Opinions & Observed Frequency & $\begin{array}{c}\text { Expected } \\
\text { Frequency }\end{array}$ & Df & $\begin{array}{c}\text { Level of } \\
\text { Sig. }\end{array}$ & X2-cal & X2-tab & Decision \\
\hline $\begin{array}{l}\text { Not } \\
\text { Significant }\end{array}$ & $49(38 \%)$ & $64.0(50 \%)$ & 1 & 0.05 & 98.79 & 3.84 & \\
Significant & $79(62 \%)$ & $64.0(50 \%)$ & & & & & Significant \\
\hline
\end{tabular}

Values in parentheses are percentages $\left(X^{2}=98.79, \mathrm{df}=1, p<0.05\right)$.

Table 7. Chi-square test of the influence of class size on classroom communication.

\begin{tabular}{lccccccc}
\hline Opinions & $\begin{array}{l}\text { Observed } \\
\text { Frequency }\end{array}$ & $\begin{array}{l}\text { Expected } \\
\text { Frequency }\end{array}$ & Df & $\begin{array}{l}\text { Level } \\
\text { Sig. }\end{array}$ & ofX2-cal & X2-ab & Decision \\
\hline $\begin{array}{l}\text { Not } \\
\text { Significant }\end{array}$ & $36(28 \%)$ & $64.0(50 \%)$ & 1 & 0.05 & 99.19 & 3.84 & \\
& & & & & & Significant \\
\hline
\end{tabular}

Values in parentheses are percentages $\left(X^{2}=99.19\right.$, df $\left.=1, p<0.05\right)$.

\section{Hypothesis three}

Class size has no significant influence on senior secondary students' classroom communication. The answer to hypothesis three is presented in Table 7.

The results in Table 7 reveals that $72 \%$ of the respondents agreed that class size has significant influence on senior secondary students' classroom communication as against $28 \%$ of respondents who disagreed. The chi-square calculated value of 99.19 was greater than the chi-square table value of 3.84 checked at 0.05 level of significance and at 1 degree of freedom. The null hypothesis is therefore rejected. This implies that class size has significant influence on senior secondary students' classroom communication.

\section{Discussion of findings}

The findings of this study revealed that class size has significant influence on senior secondary students' classroom discipline in senior secondary schools in Ekiti State. This finding agrees with the finding of Jacob and Olawuyi et al. (2016) who found that there is relationship between class size and discipline of secondary school students in Yagba West of Kogi State. The finding of this study also revealed that class size has significant influence on senior secondary students' classroom engagement. This finding agrees with the finding of Majanga and Nasongo et al (2011) who found that there is relationship between class size and engagement of primary school students in Nakuru. However, the finding of the study further revealed that class size has significant influence on senior secondary students' classroom communication. By implications, the findings of this study revealed that respondents (teachers) preferred small class size (maximum of 40:1 studentteacher ratio) than large class size for effective classroom discipline, engagement and communication because in small class size they consistently enforce the classroom rule and procedures, so discipline problems are infrequent and they always encourage to engage the students in classroom discussion and also speaks or communicate clearly during classroom session without any form of barriers. The finding of this study also revealed that that insufficient/dilapidated classrooms, insufficient teaching staff, inadequate infrastructural facilities, budgetary constraints ranked the major causes of large class size

\section{Conclusion}

Evident from the findings of this study, class size significantly influence classroom discipline, engagement and communication. By implication, this implies that large class size (above 40 students per teacher in a classroom) is one of the major causes of ineffective classroom discipline, engagement and communication. However, insufficient/dilapidated classrooms, insufficient teaching staff, inadequate infrastructural facilities, budgetary constraints ranked the major causes of large class size in senior secondary schools in Ekiti State, Nigeria

\section{Recommendation}

Both public and private schools administrators should be encouraged to adopt a maximum of 40:1 student-teacher ratio (small class size) for effective classroom discipline, 
engagement and communication. Workshops, conferences or seminars should be organized by Ministry of Education for school administrators on the need to adopt small class size. Government should increase budget funding of educational sector to improve on schools infrastructural facilities and Ministry of Education and school administrators should recruit more qualified teaching staff, renovate dilapidated classrooms, build more classrooms to control the effect of large class size on students' classroom discipline, engagement and communication.

\section{REFERENCES}

Aliu, E (2015). Class size and learning environment. Ibadan: College Press.

Angelo, TA (2008). Classroom assessment techniques: $A$ Handbook for College Teachers. San Francisco: Jossey-Bass.

Ademola, EO (2014). Students' enrolment into tertiary institutions in Nigeria: The influence of the founder's reputation - A case study. Computing, Information Systems, Development Informatics \& Allied Res. J, 5(3), 55-82.

Adeyemi, TO (2012). Influence of class-size on the quality of output in secondary schools in Ekiti State, Nigeria. American-Eurasian J. of Scientific Res, 3(1), 7-14

Booze, M., \& Maoney, M. (2001). The effect of class size on the longrun growth in reaching ability and early adult. Outcomes of the Christ Church, Health and Development Study, Department of Economics, Yale University.

Creemers, B. (2012). The effective classroom. London: Cassell.

Dror, Y. (2009). School locations as a function of uniqueness, autonomy integrated and comprehensiveness: An historical model with current implication. Journal of Education Administration and History, 27(1), $35-50$.

Doyle, W. (2014). Classroom organization and management. In M. C. Wittrock (Ed.). Handbook of research on teaching (3rd ed.). New York: Macmillan.

Federal Government of Nigeria. (2013). National policy on education and 4 year strategic plan for the development of the education sector: 2011 - 2015. Yaba, Lagos: NERDC Press.

Garret, DJ. (2008).Classroom management Essentials. London: Cambride University Press

Ikolo, VE. (2011). Effect of classroom size on students' academic performance of secondary school students in Kosofe Local Government Area of Lagos State. Unpublished M.Ed Dissertation, Lagos State University Ojo.

Imoke, F. (2006). Class size and academic success among adolescent Nigerians. Ile-Ife: Obafemi Awolowo University Press Ltd.

Jacob, OA., Olawuyi, BA., \& Jacob, AJ. (2016). Relationship between class size and discipline ofsecondary school students in Yagba West of Kogi State, Nigeria. Sky Journal of Education, 4(1), 8-13.

Kedney, RJ. (2013). Performance measurement in non-advanced further education: The use of statistics. Unpublished PhD. Thesis, University of Lancaster, United Kingdom.

Mezieobi, DI. (2012). Teaching practice in socials studies education in Nigeria. Owerri: Gabtony prints Limited.

Mokobia, MO. \& Okoye, NS. (2011). Effect of class size on the teaching and learning of in secondary schools in Delta state, Nigeria. Journal of Education and Policy, 3(1), 1 - 7.

Molnar, A. (1999). Evaluating the SAGE Program: A pilot program in targeted pupil-teacher reduction in Wisconsin. Educational Evaluation and Policy Analysis, 2(1), 165-178.

Makinde, BO. (2011). Teachers and classroom climate. Journal of Research in Counseling Psychology, 6(2), 13-30
Majanga, EK., Nasongo, JW., \& Sylvia, VK. (2011). Effect of class size on classroom interaction during Mathematics discourse in the Wake of free Primary Education: A study of public primary schools in Nakuru Municipality. Current Research Journal of Social Sciences, 3(1), 44 -49.

Nosiri, CP. (2012). Classroom organization and management: Theory and practice. Owerri: Rapid Publisher.

Nwaubani, OO. (2007). Towards a competency based social studies $t$ eachers education options and implication for education sector reforms in Nigeria. A paper presented at the National Annual Conference of the institute of Education, University of Nigeria, Nsukka.

Ogunyemi AO., \& Hassan, EM. (2011). Academic self-efficacy study. Study of Educational Issues, 4(1), 3- 11.

Omwirhiren, EM., \& Anderson, FE. (2016). Effect of class size and students' attitude on academic performance in at demonstration secondary school, Ahmadu Bello University Zaria, Nigeria. IOSR J.of Res. \& Method in Education, 6(1), 1-6.

Shuaibu, AA. (2003). Effect of Class Size on Students' academic achievement in English Language presentation. Unpublished M.Ed Dissertation Ahmadu Bello University.

Sesugh, S. (2012). The class size debate: Is small better. Nigeria: Open University Press.

Tobi, DO. (2013). Effect of class size reduction on students' performance in mathematics in JSSCE examination in Ibadan Municipal. Int.I J. of Edu. Res, 1(4), 165 - 178.

Vacca, RT. (2011). Content area reading: Literacy and learning across the curriculum. Boston: Allyn and Bacon Press
Citation: Ajayi, OV., Audu, CT, Ajayi, EE. (2017). Influence of class size on students' classroom discipline, engagement and communication: a case study of senior secondary schools in Ekiti state, Nigeria. Sky.J.Edu.Res, 5(5),34-41 